\title{
Kreativitas dan Niat Berwirausaha Ditinjau dari Theory of Planned Behavior
}

\author{
Ignasia Christiyani Kore ${ }^{1}$, Wisnu Prajogo ${ }^{2}$ \\ ${ }^{1}$ Correspondence Author: christin.kore@gmail.com \\ ${ }^{1}$ Magister Manajemen STIE YKPN Yogyakarta, Indonesia \\ ${ }^{2}$ Magister Manajemen STIE YKPN Yogyakarta, Indonesia
}

INDEXING

Keywords:

Creativity;

Entrepreneurial

Intention;

Theory Of Planned

Behavior;

Kata kunci:

Creativity;

Entrepreneurial

Intention;

Theory Of Planned

Behavior:

\begin{abstract}
This study examines the moderating effect of entrepreneurship education on the relationship of creativity, attitude toward entrepreneurship, subjective norm, perceived behavioral control and entrepreneurial intention. Participants of this study are people aged more than 17 years who have and have never participated in entrepreneurship education. A total of 154 responses were used to test the proposed hypothesis. The results showed that creativity has positive effect on attitude toward entrepreneurship, subjective norm and perceived behavioral control. In addition, attitude toward entrepreneurship and perceived behavioral control have positive effect on entrepreneurial intention. However, no significant effect was found between subjective norm and entrepreneurial intention. Other findings in this study are entrepreneurship education that positively moderates the relationship of creativity, attitude toward entrepreneurship, subjective norm, perceived behavioral control and entrepreneurial intention. An interesting result in this study is the existence of moderating effect of entrepreneurship education. The relationship among variables are stronger for respondents who have attended entrepreneurship education. The results of this study indicate that entrepreneurship education has an important role in increasing one's intention to become entrepreneurs.
\end{abstract}

\begin{abstract}
ABSTRAK
Penelitian ini menguji efek moderasi entrepreneurship education pada hubungan creativity, attitude toward entrepreneurship, subjective norm, perceived behavioral control dan entrepreneurial intention. Responden dalam penelitian ini adalah masyarakat umum dengan umur lebih dari 17 tahun yang pernah dan belum pernah mengikuti entrepreneurship education. Sebanyak 154 tanggapan digunakan untuk menguji hipotesis yang diajukan. Hasil penelitian menunjukkan bahwa creativity berpengaruh positif pada attitude toward entrepreneurship, subjective norm dan perceived behavioral control. Selain itu, attitude toward entrepreneurship dan perceived behavioral control berpengaruh positif pada entrepreneurial intention. Akan tetapi, tidak ditemukan pengaruh yang signifikan antara subjective norm dan entrepreneurial intention. Penemuan lain dalam penelitian ini adalah entrepreneurship education memoderasi secara positif hubungan creativity, attitude toward entrepreneurship, subjective norm, perceived behavioral control dan entrepreneurial intention. Hasil yang menarik dalam penelitian ini adalah didukungnya efek moderasi entrepreneurship education. Hubungan antar variable lebih kuat pada responden yang pernah mengikuti entrepreneurship education dibandingkan dengan responden yang belum pernah mengikuti entrepreneurship education. Hasil dari penelitian ini mengindikasikan bahwa entrepreneurship education mempunyai peranan penting dalam meningkatkan niat seseorang untuk berwirausaha.
\end{abstract}

\section{PENDAHULUAN}

Kewirusahaan berperan penting dalam mendorong pembangunan ekonomi dan mengurangi pengangguran (Sesen, 2013). Salah satu bentuk realisasi dari kewirausahaan adalah banyak berdirinya UMKM. Berdasarkan data dari website resmi Kementrian Koperasi dan Usaha Kecil Menengah, perkembangan UMKM tahun 2016-2017 mengalami peningkatan dari 61.651.177 menjadi 62.922.617 untuk unit usaha. Berkembangnya 
kewirausahaan berpotensi meningkatkan pertumbuhan dan pembangunan ekonomi suatu negara. Beberapa kontribusi dari perkembangan kewirausahaan di suatu negara seperti peningkatan struktur ekonomi, kemajuan teknologi dan penciptaan lapangan kerja yang berdampak pada kemakmuran ekonomi suatu negara (Ghulam, 2008; Gurel et al., 2010; Li et al., 2008).

Perkembangan kewirausahaan tak lepas dari tingginya minat masyarakat untuk berwirausaha. Kunci dari perkembangan kewirausahaan adalah meningkatkan entrepreneurial intention atau niat berwirausaha masyarakat. Secara umum, munculnya entrepreneurial intention dipengaruhi oleh faktor internal dan faktor eksternal seseorang. Secara eksternal, entrepreneurial intention dipengaruhi oleh tingkat pendidikan, pelatihan dan kesempatan untuk menciptakan usaha baru (Chen et al., 1998; Krueger et al., 2000). Secara internal, munculnya entrepreneurial intention dipengaruhi oleh kemampuan seseorang dalam mengenali sebuah peluang, toleransi terhadap ambiguitas dan kreativitas (Teng, 2007; Vesalainen \& Pihkala, 1999; Zahra et al., 2005). Kemampuan individual akan mempengaruhi kepercayaan diri dan keyakinannya untuk berkarir menjadi seorang wirausahawan.

Entrepreneurship education dan kreativitas merupakan variabel eksternal dan internal seseorang yang mempengaruhi entrepreneurial intention dan saling berkaitan. González (2019) menemukan bahwa seseorang yang mempunyai latar belakang pendidikan kewirausahaan akan mempunyai kemampuan untuk survive dalam dunia wirausaha. Dampak dari pemberian entrepreneurship education akan mendorong seseorang untuk lebih kreatif untuk menghadapi kondisi yang tidak pasti. Salah satu poin penting dalam entrepreneurship education adalah kreativitas. Entrepreneurship education akan mendorong seseorang untuk bertindak kreatif dalam segala kondisi sehingga dalam beradaptasi, mengatasi kesulitan, menyikapi ketidakpastian, dan mendukung perubahan. Entrepreneurship education dapat diberikan di kampus atau lembaga pendidikan formal, informal maupun pemerintah.

Pendidikan ini dapat berupa simulasi bisnis, kompetisi rencana bisnis, kuliah, studi kasus, atau kegiatan langsung (Krueger, 1994; Kuratko, 2005). Sedangkan kreativitas diartikan sebagai kemampuan seseorang dalam menciptakan ide dan produk baru dengan menggabungkan atau menggunakan kembali ide-ide yang sudah ada sebelumnya (Plucker, 2004). Kreativitas dianggap sebagai jantung pengembangan sebuah usaha (Hamidi et al., 2008). Kreativitas bukan bakat yang dimiliki seseorang melainkan sebuah kemampuan intelektual yang didapatkan dan diasah melalui salah satunya adalah pemberian pengetahuan melalui entrepreneurship education. Entrepreneurship education akan memotivasi seseorang untuk berpikir "out of the box" sehingga memberikan ide dan solusi yang inovatif (Sternberg, 2004), akibatnya, kepercayaan diri, keyakinan dan entrepreneurial intention atau niat seseorang untuk menjadi seorang wirausaha akan tetap terjaga atau bahkan lebih tinggi.

Sebelumnya, untuk menjelaskan anteseden entrepreneurial intention, beberapa peneliti menggunakan teori TPB atau Theory of planned behavior (Ajzen, 1991). Teori ini menjelaskan bahwa munculnya entrepreneurial intention tergantung pada pengaruh variabel attitude, subjective norms, dan perceived behavioral control (Ajzen, 1991). Beberapa penelitian terdahulu membuktikan bahwa teori TPB menjadi teori yang relevan untuk menerangkan entrepreneurial intention. Attitude, subjective norms, dan perceived 
behavioral control terbukti mempengaruhi entrepreneurial intention (Kolvereid, 1996; Krueger,2000; Veciana, 2005).

Selain itu, entrepreneurship education dan kreativitas terbukti mempengaruhi intention baik secara langsung maupun melalui attitude, subjective norm dan perceived behavioral control (Souitaris, 2007; Zampetakis, 2011; Hunter et al., 2007; Rauch \& Hulsink, 2015; Biraglia \& Kadile, 2017; González et al., 2019). Meskipun beberapa peneliti sebelumnya telah meneliti entrepreneurial intention menggunakan teori TPB (Rauch \& Hulsink, 2015; Tiwari et al., 2017; Biraglia, 2017; González, 2019), namun masih jarang penelitian yang mengombinasikannya dengan variabel entrepreneurship education dan creativity dalam satu penelitian. Dalam penelitian ini, peneliti akan menggabungkan entrepreneurship education dan creativity dalam satu model penelitian. Tujuan utama penelitian ini adalah: 1) menguji hubungan creativity, attitude, subjective norm, perceived behavioral control dan entrepreneurial intention, 2) menguji efek moderasi entrepreneurship education pada model hubungan creativity, attitude, subjective norm, perceived behavioral control dan entrepreneurial intention,3) menguji perbandingan efek moderasi entrepreneurship education pada responden yang pernah mengikuti entrepreneurship education dengan responden yang belum pernah mengikuti entrepreneurship education.

\section{TINJAUAN PUSTAKA}

\section{Creativity}

Creativity adalah kemampuan seseorang untuk menciptakan hal ide atau produk baru dengan cara mengombinasikan, menambahkan atau menggunakan kembali ide yang sudah ada (Plucker et al., 2004). Kreativitas dianggap sebagai jantung pengembangan sebuah usaha (Yar et al., 2008). Kreativitas merupakan kerangka kerja intelektual yang memotivasi mereka untuk berpikir "out of the box" sehingga memberikan solusi yang inovatif (Sternberg, 2004).

\section{Attitude toward Entrepreneurship}

Attitude toward entrepreneurship adalah persepsi individu terhadap apakah sebuah perilaku dapat menguntungkan atau tidak menguntungkan jika dilakukan atau tidak dilakukan, khususnya persepsi individu pada kegiatan wirausaha (Ajzen, 1991). Terkait dengan kewirausahaan, attitude adalah persepsi seorang individu yang dapat memengaruhi sikap positif dan intensinya pada entrepreneurship. Entrepreneurship akan dianggap sebagai suatu hal yang positif secara umum dan berpotensi mendatangkan keuntungan (Al Mamun \& Fazal., 2018).

\section{Subjective Norm}

Subjective norm merupakan persepsi seseorang tentang perilaku yang sesuai atau tidak sesuai dengan persepsi orang lain tentang perilaku tersebut, khususnya kegiatan wirausaha (Ajzen, 1991). Subjective norm juga diartikan sebagai keyakinan akan suatu norma subyektif yang terbentuk dari suatu keyakinan normatif berhubungan dengan persepsi sebuah kelompok atau individu rujukan yang akan mendukung atau tidak mendukung perilaku kita (Veciana et al., 2005). 


\section{Perceived Behavioral Control}

Perceived behavioral control adalah persepsi individu mengenai kemampuan pribadi mereka untuk melakukan tindakan apakah mampu atau tidak mampu, khususnya mampu atau tidak mampu untuk memulai kegiatan wirausaha (Ajzen, 1991). Linan \& Chen (2009) menekankan bahwa perceived behavioral control lebih terfokus pada tingkat keyakinan dan kepercayaan diri seseorang akan kemampuan dan kapabilitasnya untuk membuat dan memulai sebuah usaha. Keyakinan dan kepercayaan diri merupakan determinan yang sangat kuat yang memengaruhi niat dan tindakan seseorang.

\section{Entrepreneurial Intention}

Entrepreneurial intention merupakan rencana dan niat seorang individu untuk menjadi seorang wirausahawan di saat belum ada tindakan yang dilakukan untuk mewujudkan niat dan rencana tersebut (Moriano et al., 2012). Dalam menciptakan suatu usaha baru, diawali dengan muncul niat untuk berwirausaha. Niat berwirausaha merupakan langkah awal dan menjadi dasar seorang individu untuk memulai usaha baru. Niat berwirausaha belum diikuti tindakan atau perilaku untuk mewujudkan niat tersebut (Boldewes el al., 2008).

\section{Entrepreneurship Education}

Entrepreneurship education proses pembelajaran, pelatihan, dan pemberian pengetahuan tentang kewirausahaan kepada seseorang baik dari lingkungan sekolah (formal), kursus (informal), dan pelatihan pemerintah (Kuratko, 2005: Rauch \& Hulsink, 2015). Menurut González et al. (2019), entrepreneurship education merupakan kegiatan yang sangat penting untuk membekali seseorang dengan kompetensi dan pengetahuan yang cukup untuk memasuki dunia usaha. Entreprenerurship education memberikan ketahanan, perkiraan yang matang, dan kepercayaan diri yang tinggi bagi seseorang yang akan memasuki dunia usaha.

Model dan Hipotesis

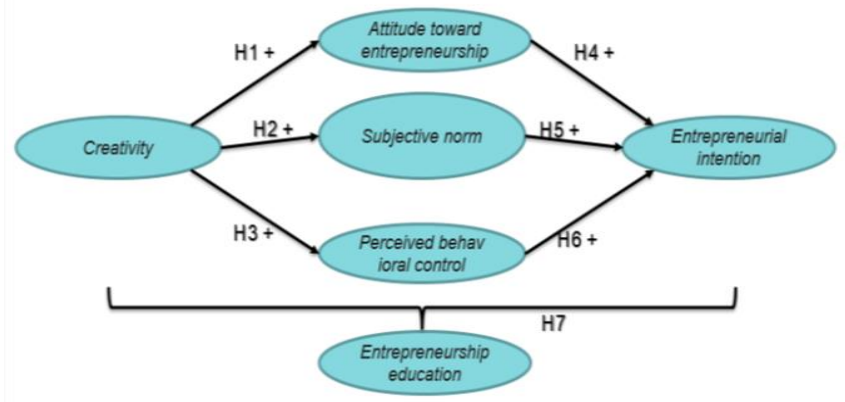

Gambar 1. Model Penelitian

Pengaruh creativity pada attitude toward entrepreneurship.

Kreativitas dianggap sebagai jantung pengembangan sebuah usaha (Yar et al., 2008). Kreativitas merupakan kerangka kerja intelektual yang memotivasi mereka untuk berpikir "out of the box" sehingga memberikan solusi yang inovatif (Sternberg et al., 2004). Baron (2004) menemukan fakta bahwa wirausahawan harus lebih kreatif dibandingkan dengan orang lain dalam menciptakan dan menggunakan peluang. Oleh karena itu, kreativitas 
dianggap sebagai salah satu elemen terpenting untuk membentuk niat berwirausaha. Gorman et al. (2007), Feldman \& Bolino (2000) dan Hamidi et al. (2008) menemukan bahwa kreativitas yang tinggi mempengaruhi proses pembentukan niat secara positif. Selanjutnya, Zampitakis (2011) dan Tiwari et al. (2017) membuktikan bahwa kreativitas juga secara positif mempengaruhi sikap seseorang sehingga memilih wirausaha sebagai karier. Berdasarkan uraian sebelumnya, peneliti merumuskan hipotesis sebagai berikut:

\section{H1: Creativity berpengaruh positif pada attitude toward entrepreneurship}

\section{Pengaruh creativity pada subjective norm}

Subjective norm merupakan persepsi individu tentang perilaku yang sesuai atau tidak sesuai dengan persepsi orang lain tentang perilaku tersebut. Subjective norm mempengaruhi seseorang untuk melakukan atau tidak melakukan sesuatu dengan melalui persepsi orang lain yang ada di sekitar seperti teman, keluarga, tetangga, mentor, dan lain-lain (Ajzen, 1991). Linan \& Chen (2009) lebih menekankan bahwa tekanan akan muncul dari lingkungan keluarga, teman dekat, dan orang-orang penting di sekitar kita. Niat seseorang akan sangat dipengaruhi oleh tekanan dari orang-orang disekitarnya, termasuk keyakinannya untuk membuat dan memulai sebuah usaha. Tiwari (2017) menemukan bahwa kreativitas mempengaruhi perceived behavior control secara positif. Individu yang kreatif selalu mempunyai cara untuk memecahkan sebuah masalah. González et al. (2019) mengatakan bahwa seseorang yang kreatif akan mempunyai daya tahan yang kuat untuk survive. Seseorang yang kreatif akan selalu mencari cara untuk keluar dari situasi yang sulit, selalu berusaha untuk tetap tumbuh dalam situasi yang sulit, dan bahkan, seorang yang kreatif akan mencari cara untuk mengubah kerugian menjadi sebuah keuntungan. Tekanan yang diterima dari lingkungan tidak akan terlalu berengaruh terhadap orang-orang yang kreatif.

Mereka akan selalu berusaha untuk mencari cara bagaimana bertahan dalam tekanan keluarga, lingkungan, dan orang-orang terdekat. Mereka akan selalu berusaha untuk mengambil hati dan dukungan orang-orang sekitar dengan cara yang kreatif. Berdasarkan uraian sebelumnya, peneliti merumuskan hipotesis sebagai berikut:

$\mathrm{H} 2$ : Creativity berpengaruh positif pada subjective norm

\section{Pengaruh creativity pada perceived behavioral control}

Linan \& Chen (2009) menekankan bahwa perceived behavioral control lebih terfokus pada tingkat keyakinan dan kepercayaan diri seseorang akan kemampuan dan kapabilitasnya untuk membuat dan memulai sebuah usaha. Keyakinan dan kepercayaan diri merupakan determinan yang sangat kuat yang mempengaruhi niat dan tindakan seseorang. Menurut González et al. (2009), orang-orang kreatif akan mencari cara untuk menciptakan dan menggunakan sebuah peluang. Mereka akan selalu mencari cara untuk memanfaatkan sumber daya dan kemampuan yang mereka miliki dengan sebaik-baiknya. Seseorang yang kreatif akan selalu berusaha untuk mengatasi keterbatasan dan kendala yang mereka jumpai, sehingga orang yang kreatif mempunyai tingkat keyakinan dan kepercayaan diri yang tinggi (Boyd \& Vozikis, 1994).

Selanjutnya, Ernst (2011) menguji peran kreativitas dalam memprediksi social entrepreneurship intention. Hasilnya, kreativitas tidak hanya kuat mempengaruhi sikap secara positif, namun kreativitas juga mempengaruhi perceived behavior control. Tiwari et 
al. (2017) mengonfirmasi penemuan sebelumnya dengan membuktikan bahwa kreativitas mempengaruhi perceived behavior control secara positif. Berdasarkan uraian sebelumnya, peneliti merumuskan hipotesis sebagai berikut:

H3: Creativity berpengaruh positif pada perceived behavioral control

Pengaruh attitude toward entrepreneurship pada entrepreneurial intention

Menurut Ajzen (1991) niat dipengaruhi oleh theory of planned behavior di mana terdapat 3 faktor di dalamnya yaitu attitude, subjcetive norm dan perceived behavioral control. Tiwari et al. (2017) menguji pengaruh attitude, pada social entrepreneurial intention. Hasilnya, attitude berpengaruh positif pada social entrepreneurial intention. Lingkungan sosial berperan penting dalam menjaga keyakinan, kepercayaan diri dan motivasi seseorang untuk menjadi seorang wirausahawan. Persepsi positif seseorang mengenai wirausaha menjadi pendorong untuk memiliki ketertarikan yang memunculkan niat seseorang untuk menjadi seorang wirausahawan (Hedner et al., 2011). Selanjutnya, Habeeb \& Ahmad (2018) dan González et al. (2019) juga menemukan bahwa attitude berpengaruh positif terhadap entrepreneurial intention. Berdasarkan uraian sebelumnya, peneliti merumuskan hipotesis sebagai berikut:

H4: Attitude toward entrepreneurship berpengaruh positif pada entrepreneurial intention

Pengaruh subjective norm pada entrepreneurial intention

Tiwari et al. (2017) menguji pengaruh subjective norm pada social entrepreneurial intention. Hasilnya, subjective norm berpengaruh positif pada social entrepreneurial intention. Artinya, lingkungan sosial berperan penting dalam menjaga keyakinan, kepercayaan diri dan motivasi seseorang untuk menjadi seorang wirausahawan. Selanjutnya, Habeeb \& Ahmad (2018) dan González et al. (2019) juga menemukan bahwa subjective norm berpengaruh positif terhadap entrepreneurial intention. Lingkungan sosial yang buruk dan tidak mendukung berpotensi menghilangkan niat dan motivasi seseorang untuk berwirausaha (Hedner et al., 2011).

Seorang individu didukung oleh orang-orang terdekatnya sehingga akan meningkatkan niat untuk menjadi seorang wirausahawan. Berdasarkan uraian sebelumnya, peneliti merumuskan hipotesis sebagai berikut:

H5: Subjective norm berpengaruh positif pada entrepreneurial intention

Pengaruh perceived behavioral control pada entrepreneurial intention

Tiwari et al. (2017) menguji pengaruh perceived behavioral control pada entrepreneurial intention. Hasilnya, perceived behavioral control berpengaruh positif pada social entrepreneurial intention. Seseorang yang mempunyai kepercayaan diri atas kemampuan yang dimiliki akan mendorongnya untuk memiliki niat yang tinggi menjadi seorang wirausahawan. Perceived behavioral control merupakan salah satu komponen yang membentuk niat seseorang (Ajzen, 1991). Selanjutnya, Habeeb \& Ahmad (2018) dan González et al. (2017) membuktikan bahwa perceived behavioral control berpengaruh positif terhadap entrepreneurial intention. Berdasarkan uraian sebelumnya, peneliti merumuskan hipotesis sebagai berikut:

H6: Perceived behavioral control berpengaruh positif pada entrepreneurial intention 
Entrepreneurship education memoderasi hubungan creativity, attitude toward entrepreneuship, subjective norm, perceived behavioral control dan entrepreneurial intention.

Selain menyoroti peran penting keluarga dan lingkungan sosial, Bernard \& Barbosa (2016) dan Yang \& Danes (2017) juga menyoroti peran yang dimainkan oleh para mentor kewirausahaan dalam menjamin kesuksesan karir berwirausaha. Mentor kewirausahaan mempunyai peranan penting dalam melatih, mendidik dan membina seseorang untuk menjadi seorang wirausaha yang mempunyai kreativitas, inovasi dan pengetahuan yang tinggi. Menurut, Kuratko (2005) entrepreneurship education adalah proses pembelajaran, pelatihan, dan pemberian pengetahuan tentang kewirausahaan kepada seseorang baik dari lingkungan sekolah (formal), kursus (informal), dan pelatihan pemerintah.

Pemberian mata kuliah kewirausahaan oleh pihak sekolah, pemberian kursus kewirausahaan baik dari level individu atau instansi informal, dan pelatihan kewirausahaan yang diselenggarakan oleh pemerintah menjadi pemicu naiknya ketertarikan untuk membuat sebuah usaha yang baru.

Rauch \& Hulsink (2015) dan González et al. (2019) menemukan bahwa entrepreneurship education dapat menaikkan intensi seseorang untuk berwirausaha. Lebih jauh, entrepreneurship education mempengaruhi entrepreneurial behavior. Selain itu, entrepreneurship education juga mempengaruhi attitude toward entrepreneurship, subjective norm dan perceived behavioral control.

Dalam penelitian González et al. (2019), pemberian entrepreneurship education dalam kelompok eksperimen dengan partisipan pelajar berdampak pada kemampuan dan ketertarikannya terhadap kewirausahaan. Hal ini didasari pada pengaruh entrepreneurship education pada sisi internal partisipan maupun eksternal partisipan. Entrepreneurship education secara langsung maupun tidak langsung dapat berdampak pada bagaimana seseorang menilai kewirausahaan. Kreativitas, attitude, subjective norm dan perceived behavioral control merupakan bagian internal seseorang yang saling berhubungan Tiwari et al. (2017).

Entrepreneurship education mempunyai peranan untuk mengasah kreativitas, mental, pemikiran dan sikap yang lebih positif. Oleh karena itu, Entrepreneurship education dapat memperkuat hubungan kreativitas, attitude, subjective norm dan perceived behavioral control. Dalam konteks entrepreneurial intention, entrepreneurship education dapat meningkatkan sikap positif, norma subjektif dan perceived behavioral control. Pendidikan memberikan gambaran tentang kewirausahaan dengan framing yang positif sehingga hal ini berdampak pada persepsi seseorang akan menjadi positif. Selanjutnya, pendidikan kewirausahaan juga memberikan gambaran mengenai norma subjektif terkait kewirausahaan yang dipegang, serta memberikan motivasi dan semangat bahwa individu mempu menjadi seorang wirausaha.

Dapat disimpulkan bahwa pengaruh entrepreneurship education berpotensi dapat memperkuat hubungan antara creativity, attitude toward entrepreneurship, subjective norm, perceived behavioral control dan entrepreneurial intention. Pengaruh creativity pada attitude toward entrepreneurship, subjective norm dan perceived behavioral control akan lebih kuat ketika individu pernah mengikuti pendidikan atau pelatihan kewirausahaan dibandingkan dengan individu yang belum pernah mengikuti pendidikan atau pelatihan kewirausahaan. Selanjutnya, pengaruh attitude toward entrepreneurship, subjective norm dan perceived behavioral control pada entrepreneurial intention akan lebih kuat ketika 
individu pernah mengikuti pendidikan atau pelatihan kewirausahaan dibandingkan dengan individu yang belum pernah mengikuti pendidikan atau pelatihan kewirausahaan. Berdasarkan uraian sebelumnya, peneliti merumuskan hipotesis sebagai berikut:

H7: Entrepreneurship education memoderasi hubungan creativity, attitude toward entrepreneurship, subjective norm, perceived behavioral control dan entrepreneurial intention.

\section{METODE PENELITIAN}

Penelitian ini menggunakan kuesioner online dan offline sebagai alat mengumpulkan data. Pengumpulan data dalam penelitian ini menggunakan teknik purposive sampling, dimana responden yang ikut serta dalam penelitian ini harus berusia lebih dari 17 tahun. Responden dibagi menjadi kelompok responden yang pernah mengikuti pendidikan kewirausahaan dan yang belum pernah mengikuti pendidikan kewirausahaan. Sebanyak 154 responden telah mengikuti penelitian ini.

Tabel.1

Demografi Responden

\begin{tabular}{|l|l|l|}
\hline Kriteria & Klasifikasi & Jumlah Responden \\
\hline Jenis Kelamin & Laki-Laki & 56 \\
\hline \multirow{4}{*}{ Usia } & Perempuan & 98 \\
\hline \multirow{3}{*}{ Pendidikan Terakhir } & $17-22$ tahun & 54 \\
& $23-28$ tahun & 81 \\
& $>28$ tahun & 19 \\
& SLTA & 60 \\
& Diploma & 6 \\
& Strata 1 & 76 \\
& Strata 2 & 12 \\
\hline Pendidikan kewirausahaan & Pernah & 102 \\
\cline { 2 - 3 } & Belum Pernah & 52 \\
\hline Pendidikan Kewirausahaan & Sekolah/Kampus & 82 \\
\cline { 2 - 3 } & Seminar & 4 \\
\cline { 2 - 3 } & Kursus & 11 \\
\cline { 2 - 3 } & Lainnya & 5 \\
\hline Periode & $1-3$ bulan yang lalu & 15 \\
\cline { 2 - 3 } $\begin{array}{l}\text { Kendidikan } \\
\text { Kewirausahaan }\end{array}$ & 4-6 bulan yang lalu & 24 \\
\cline { 2 - 3 } & $>6$ bulan yang lalu & 63 \\
\hline
\end{tabular}

Dalam penelitian ini, variabel creativity diukur dengan 6 item pernyataan dengan menggunakan skala likert 5 yang diadopsi dari penelitian Cardon et al. (2013) dengan alpha $=0,887$. Dengan salah satu item pertanyaan "Saya sering menemukan solusi kreatif untuk sebuah masalah". Dalam penelitian ini, variabel attitude toward entrepreneurship diukur dengan 5 item pertanyaan dengan menggunakan skala likert 5 yang diadopsi dari penelitian Linan \& Chen (2009) dengan alpha=0,874. Dengan salah satu item pertanyaan "Menjadi seorang pengusaha menyiratkan banyak keuntungan daripada kerugian bagi saya". untuk variabel subjective norm diukur dengan 3 item pertanyaan dengan menggunakan skala likert 5 yang diadopsi dari penelitian Linan \& Chen (2009) dengan 
alpha $=0,874$. Dengan salah satu item pertanyaan "Keluarga saya akan menyetujui keputusan saya menjadi pengusaha".

Selanjutnya, variabel perceived behavior control diukur dengan 3 item pertanyaan dengan menggunakan skala likert 5 yang diadopsi dari penelitian Linan \& Chen (2009) dengan alpha=0,892. Dengan salah satu item pertanyaan" Memulai sebuah usaha sambil tetap bekerja akan mudah bagi saya". Dalam penelitian ini, variabel entrepreneurial intention diukur dengan 6 item pertanyaan dengan menggunakan skala likert 5 yang diadopsi dari penelitian Linan \& Chen (2009) dengan alpha=0,920. Dengan salah satu item pertanyaan "Saya siap melakukan apa saja untuk menjadi wirausaha".

Variabel entrepreneurship education merupakan variabel dikotomi yang digunakan untuk membagi responden kedalam kelompok responden yang pernah mengikuti kelas, kursus atau pelatihan kewirausahaan (1) dan kelompok responden yang belum pernah sama sekali mengikuti (0). Entrepreneurship education menggunakan pertanyaan "Apakah Anda pernah mengikuti kelas kewirausahaan baik di sekolah (formal) atau mengikuti kursus/seminar kewirausahaan (informal) atau mengikuti pelatihan kewirausahaan dari pemerintah?."

\section{HASIL DAN PEMBAHASAN}

Pengujian hipotesis dalam penelitian ini menggunakan AMOS 24. Sebelumnya, peneliti melakukan uji Goodfitness Model dengan nilai fit Chi Square 0,0032 < 0,05 ( kurang baik), GFI 0,982 > 0,9 (baik), RMR 0,009 < 0,08 (baik), RMSEA 0,127 > 0,08 (kurang baik), AGFI 0,868>0,8 (baik), NFI 0,988 > 0,9 (baik), CFI 0,991 > 0,9 (baik), TLI 0,955 > 0,9 (baik), dan CMIN/DF 3,449 (baik). Berdasarkan uji fit, model penelitian ini termasuk dalam kategori baik. Selanjutnya peneliti melakukan pengujian hipotesis dengan hasil yang ditunjukkan pada tabel 2 dan tabel 3 .

Tabel 2

Hasil Path Analysis Amos 24

\begin{tabular}{|l|c|c|c|c|}
\hline & Estimate & $\boldsymbol{S E}$ & CR & P Values \\
\hline $\mathrm{C} \rightarrow \mathrm{AT}$ & 0,750 & 0,117 & 5,983 & $<0,01$ \\
\hline $\mathrm{C} \rightarrow \mathrm{SN}$ & 0,698 & 0,118 & 6,644 & $<0,01$ \\
\hline $\mathrm{C} \rightarrow \mathrm{PBC}$ & 0,860 & 0,136 & 7,253 & $<0,01$ \\
\hline $\mathrm{AT} \rightarrow$ EI & 0,604 & 0,141 & 5,796 & $<0,01$ \\
\hline $\mathrm{SN} \rightarrow$ EI & 0,006 & 0,071 & 0,101 & 0,919 \\
\hline $\mathrm{PBC} \rightarrow$ EI & 0,385 & 0,093 & 4,577 & $<0,01$ \\
\hline
\end{tabular}

Tabel 3

Hasil Pengujian Efek Moderasi

\begin{tabular}{|l|c|c|c|c|}
\hline \multirow{2}{*}{} & \multicolumn{2}{|c|}{ Pernah } & \multicolumn{2}{c|}{ Belum pernah } \\
\cline { 2 - 5 } & Estimate & P Values & Estimate & P Values \\
\hline $\mathrm{C} \rightarrow$ AT & 0,384 & 0,007 & 0,658 & $<0,01$ \\
\hline
\end{tabular}




\begin{tabular}{|l|c|c|c|c|}
\hline $\mathrm{C} \rightarrow \mathrm{SN}$ & 0,637 & $<0,01$ & 0,597 & $<0,01$ \\
\hline $\mathrm{C} \rightarrow \mathrm{PBC}$ & 0,978 & $<0,01$ & 0,553 & $<0,01$ \\
\hline $\mathrm{AT} \rightarrow \mathrm{EI}$ & 1,496 & 0,002 & 0,646 & $<0,01$ \\
\hline $\mathrm{SN} \rightarrow$ EI & $-0,005$ & 0,961 & 0,030 & 0,744 \\
\hline $\mathrm{PBC} \rightarrow$ EI & 0,424 & $<0,01$ & 0,249 & 0,180 \\
\hline
\end{tabular}

Tabel 4

Ringkasan Hasil Pengujian Hipotesis

\begin{tabular}{|l|c|c|c|}
\hline \multicolumn{1}{|c|}{ Hipotesis } & Estimate & P-value & Hasil \\
\hline $\begin{array}{l}\text { H1: Creativity berpengaruh positif pada attitude } \\
\text { toward entrepreneurship }\end{array}$ & 0,750 & $<0,01$ & Terdukung \\
\hline $\begin{array}{l}\text { H2: Creativity berpengaruh positif pada subjective } \\
\text { norm }\end{array}$ & 0,698 & $<0,01$ & Terdukung \\
\hline $\begin{array}{l}\text { H3: Creativity berpengaruh positif pada perceived } \\
\text { behavioral control }\end{array}$ & 0,860 & $<0,01$ & Terdukung \\
\hline $\begin{array}{l}\text { H4: Attitude toward entrepreneurship berpengaruh } \\
\text { positif pada } \text { entrepreneurial intention }\end{array}$ & 0,604 & $<0,01$ & Terdukung \\
\hline $\begin{array}{l}\text { H5: Subjective Norm berpengaruh positif pada } \\
\text { entrepreneurial intention. }\end{array}$ & 0,006 & 0,919 & Tidak terdukung \\
\hline $\begin{array}{l}\text { H6: Perceived behavioral control berpengaruh } \\
\text { positif pada } \text { entrepreneurial intention }\end{array}$ & 0,385 & $<0,01$ & Terdukung \\
\hline
\end{tabular}

Pengaruh creativity pada attitude toward entrepreneurship.

Berdasarkan hasil ringkasan hipotesis yang ditunjukkan pada tabel 4 , dapat ditarik kesimpulan bahwa hipotesis 1 dalam penelitian ini terdukung $(B=0,750, \mathrm{P}<0,01)$. Hasil penelitian ini membuktikan bahwa kreativitas merupakan salah satu elemen terpenting untuk membentuk niat berwirausaha Gorman et al. (2007). Selanjutnya, hasil penelitian ini sesuai dengan hasil penelitian yang dilakukan oleh Zampitakis (2011) dan Tiwari et al. (2017) yang menemukan bahwa kreativitas juga secara positif mempengaruhi sikap seseorang sehingga memilih wirausaha sebagai karier. Seseorang yang mempunyai kreativitas yang tinggi tidak hanya pandai memanfaatkan peluang, namun juga pandai menciptakan sebuah peluang untuk berwirausaha sehingga persepsi mereka terhadap wirausaha sangat baik.

\section{Pengaruh creativity pada subjective norm}

Berdasarkan hasil ringkasan hipotesis yang ditunjukkan pada tabel 4, dapat ditarik kesimpulan bahwa hipotesis 2 dalam penelitian ini terdukung $(B=0,698, P<0,01)$. Hasil penelitian ini sejalan dengan penemuan Tiwari et al, (2017) yang menemukan bahwa kreativitas mempengaruhi PBC secara positif. Individu yang kreatif selalu mempunyai cara untuk memecahkan sebuah masalah. Sesuai dengan pendapat González et al. (2019) yang mengatakan bahwa seseorang yang kreatif akan mempunyai daya tahan yang kuat untuk 
survive. Individu yang kreatif akan selalu mencari cara untuk keluar dari situasi yang sulit, selalu berusaha untuk tetap tumbuh dalam situasi yang sulit, dan bahkan, seorang yang kreatif akan mencari cara untuk mengubah kerugian menjadi sebuah keuntungan. Tekanan yang diterima dari lingkungan tidak akan terlalu berengaruh terhadap orang-orang yang kreatif. Mereka akan selalu berusaha untuk mencari cara bagaimana bertahan dalam tekanan keluarga, lingkungan, dan orang-orang terdekat. Mereka akan selalu berusaha untuk mengambil hati dan dukungan orang-orang sekitar dengan cara yang kreatif.

Pengaruh creativity pada perceived behavioral control

Berdasarkan hasil ringkasan hipotesis yang ditunjukkan pada tabel 4 , dapat ditarik kesimpulan bahwa hipotesis 3 dalam penelitian ini terdukung $(B=0,860, P<0,01)$. Hasil penelitian ini sesuai dengan hasil penemuan dari Ernst (2011) yang menguji peran kreativitas dalam memprediksi social entrepreneurship intention. Hasilnya, kreativitas tidak hanya kuat mempengaruhi sikap secara positif, namun kreativitas juga mempengaruhi PBC. Hasil penelitian ini juga mengonfirmasi penemuan dari Tiwari et al, (2017) yang membuktikan bahwa kreativitas mempengaruhi perceived behavior control secara positif. PBC lebih terfokus pada tingkat keyakinan dan kepercayaan diri seseorang akan kemampuan dan kapabilitasnya untuk membuat dan memulai sebuah usaha. Keyakinan dan kepercayaan diri merupakan determinan yang sangat kuat yang mempengaruhi niat dan tindakan seseorang. Seseorang yang kreatif akan mempunyai keyakinan dan kepercayaan diri lebih besar untuk menjalankan sebuah usaha.

\section{Pengaruh attitude toward entrepreneurship pada entrepreneurial intention}

Berdasarkan hasil ringkasan hipotesis yang ditunjukkan pada tabel 4 , dapat ditarik kesimpulan bahwa hipotesis 4 dalam penelitian ini terdukung $(B=0,604, P<0,01)$ Hasil penelitian ini sesuai dengan hasil penemuan dari Habeeb \& Ahmad (2018) dan González et al. (2019) yang menemukan bahwa attitude berpengaruh positif terhadap entrepreneurial intention. Artinya, seseorang yang mempunyai persepsi dan pandangan yang positif terhadap dunia wirausaha akan mempunyai niat dan semangat berwirausaha yang tinggi. Persepsi yang positif seseorang tentang kewirausahaan akan menaikkan ketertarikan seseorang untuk menjadi seorang wirausahawan. Sebaliknya, ketika seseorang mempunyai persepsi negatif tentang kewirausahaan akan mendorong orang tersebut tidak menyukai dan cenderung tidak mau menjadi seorang wirausahawan.

\section{Pengaruh subjective norm pada entrepreneurial intention}

Berdasarkan hasil ringkasan hipotesis yang ditunjukkan pada tabel 4 , dapat ditarik kesimpulan bahwa hipotesis 5 dalam penelitian ini tidak terdukung $(B=0,006, P=0,919)$. Hasil penelitian ini tidak sesuai dengan hasil penemuan dari Habeeb \& Ahmad (2018) dan González et al. (2019) yang menemukan bahwa subjective norm berpengaruh positif terhadap entrepreneurial intention. Hal ini mungkin disebabkan oleh karakteristik responden yang tidak terlalu mementingkan norma subjektif. Responden penelitian ini yang semuanya merupakan masyarakat Indonesia dengan karakteristik Asia atau ketimuran yang mempunyai nilai kolektif yang cukup tinggi sehingga norma sibjektif seringkali diabaikan.

\section{Pengaruh perceived behavioral control pada entrepreneurial intention}

Berdasarkan hasil ringkasan hipotesis yang ditunjukkan pada tabel 5, dapat ditarik kesimpulan bahwa hipotesis 6 dalam penelitian ini terdukung $(B=0,385, \mathrm{P}<0,01)$. Hasil 
penelitian ini sesuai dengan hasil penemuan dari Habeeb \& Ahmad (2018) dan González et al. (2019) yang menemukan bahwa PBC berpengaruh positif terhadap entrepreneurial intention. Artinya, seseorang yang mempunyai keyakinan dan kepercayaan diri yang tinggi akan mempengaruhi niat untuk berwirausaha. Seseorang yang percaya diri dengan kemampuannya atau merasa mampu untuk menjadi seorang wirausahawan akan memunculkan niat wirausaha yang tinggi. Sebaliknya, jika seseorang tidak mempunyai kepercayaan diri atas kemampuan yang dimilikinya maka orang tersebut akan ragu untuk menjadi seorang wirausahawan.

Entrepreneurship education memoderasi hubungan creativity, attitude toward entrepreneuship, subjective norm, perceived behavioral control dan entrepreneurial intention.

Berdasarkan tabel di atas, menunjukan bahwa adanya pengaruh moderasi entrepreneurship education secara parsial. Semua nilai ßeta atau estimate berbeda menunjukan adanya perbedaan pengaruh antara bagian responden yang pernah mengikuti entrepreneurship education dan belum pernah mengikuti. Pada umumnya pengaruh lebih kuat bagi responden yang yang sudah pernah mengikuti entrepreneurship education.

Pertama, pengaruh creativity pada attitude toward entrepreneurship lebih kuat bagi responden yang belum pernah mengikuti entrepreneurship education $(\beta=0,658>\beta=$ 0,384). Attitude merupakan bawaan seseorang, orang yang belum pernah mengenyam pendidikan kewirausahaan bisa mempunyai pikiran yang lebih luas daripada orang yang pernah mengikutinya. Selain itu, hal ini disebabkan oleh perkembangan teknologi memunculkan berbagai platform digital yang mudah diakses untuk khalayak umum. Media sosial yang dapat diakses oleh semua kalangan secara tidak langsung sering menampilkan konten yang terkait dengan wirausaha.

Seseorang yang belum pernah sama sekali mengenyam pendidikan kewirausahaan seperti sekolah, seminar, kursus dan lainnya, secara tidak sengaja juga mendapatkan ilmu dari platform sosial tersebut. Akibatnya, seorang yang mempunyai jiwa yang kreatif akan mempunyai wawasan yang tidak kalah luas dibandingkan orang yang sering mengikuti pendidikan kewirausahaan sehingga persepsi mereka mengenai kewirausahaan bisa lebih positif. Dalam pendidikan kewirausahaan, kualitas pendidikan yang diberikan berbeda-beda sehingga seseorang yang mendapatkan pendidikan kewirausahaan pikiranya tidak bebas malah akan di frame sehingga pengaruh creativity pada attitude toward entrepreneurship akan menurun untuk responden yang pernah mendapatkan entrepreneurship education.

Kedua, pengaruh creativity pada subjective norm menunjukkan bahwa responden yang telah mengikuti entrepreneurship education mempunyai pengaruh yang lebih kuat dibandingkan dengan responden yang belum pernah mengikuti $(\beta=0,637>\beta=0,597)$. Hal ini terjadi karena pendidikan kewirausahaan akan mendorong orang yang kreatif semakin yakin dengan norma subyektif yang diyakini. Ilmu-ilmu yang didapatkan memperkuat keyakinan mereka terhadap kewirausahaan sehingga apapun apapun yang dikatakan oleh orang sekitar tidak serta merta dapat mempengaruhi keyakinan yang mereka miliki.

Ketiga, pengaruh creativity pada perceived behavioral control menunjukkan bahwa responden yang pernah mengikuti entrepreneurship education mempunyai pengaruh yang lebih kuat dibandingkan dengan responden yang belum pernah mengikuti dapat dilihat dari nilai $(\beta=0,978>\beta=0,553)$. Pendidikan memberikan kepercayaan diri kepada setiap 
individu yang mengikutinya. Pengetahuan dan skill yang didapatkan melalui pendidikan kewirausahaan lebih dapat meningkatkan kepercayaan diri mereka untuk menjadi seorang wirausahawan. Meskipun kreativitas dimiliki semua orang, namun mereka yang mengenyam pendidikan kewirausahaan akan lebih dapat mengolah dan mengasah kemampuan dan kreativitasnya.

Keempat, pengaruh attitude toward entrepreneurship pada entrepreneurial intention menunjukkan bahwa responden yang telah mengikuti entrepreneurship education mempunyai pengaruh yang lebih kuat dibandingkan dengan responden yang belum pernah mengikuti $(\beta=1,496>\beta=0,646)$. Temuan ini menunjukkan bahwa pendidikan kewirausahaan dapat lebih mendorong seseorang untuk mempunyai ketertarikan dan niat berwirausaha. Artinya, seseorang yang mempunyai sikap dan persepsi yang positif terhadap kewirausahaan akan lebih terdorong untuk menjadi seorang wirausaha apabila mereka mengikuti pendidikan kewirausahaan dibandingkan seseorang yang belum pernah mengikutinya.

Selanjutnya, terdapat persamaan hasil pengaruh subjective norm pada entrepreneurial intention untuk responden yang pernah dan belum pernah mengikuti pendidikan kewirausahaan $(\beta=-0,005 ; \beta=0,030)$. yaitu entrepreneurship education tidak memoderasi hubungan subjective norm dan entrepreneurial intenion. Dapat disimpulkan bahwa, pendidikan kewirausahaan tidak serta merta dapat membuat lingkungan sekitar berpihak dan mendukung kita untuk menjadi seorang wirausaha. Menurut peneliti, entrepreneurship education merupakan faktor internal yang hanya kita yang merasakan dampaknya, sedangkan subjective norm bersumber dari pemikiran orang lain yang dapat mempengaruhi pemikiran kita, artinya, persepsi kita tentang dukungan orang sekitar tidak tergantung dari seberapa sering kita mengikuti pendidikan kewirausahaan.

Terakhir, pengaruh perceived behavioral control pada entrepreneurship intention menunjukkan bahwa responden yang telah mengikuti entrepreneurship education mempunyai pengaruh yang lebih kuat dibandingkan dengan responden yang belum pernah mengikuti $(\beta=0,424>\beta=0,246)$. Dapat disimpulkan bahwa pendidikan kewirausahaan meningkatkan kepercayaan diri seseorang. Mereka akan lebih yakin dengan kemampuannya ketika sudah mengikuti pendidikan kewirausahaan. Keyakinan dan kepercayaan diri atas kemampuan yang dimiliki mendorongnya mempunyai niat menjadi seorang wirausaha.

Secara keselurahan, hasil pengujian efek moderasi entrepreneurship education menunjukkan bahwa pendidikan kewirausahaan sangat dianjurkan untuk diberikan kepada masyarakat agar entrepreneurial intention dapat terjaga sehingga potensi untuk munculnya wirausahawan yang baru akan selalu ada. Pendidikan kewirausahaan secara formal maupun informal seperti sekolah, seminar, kursus dan lainnya masih sangat dibutuhkan.

\section{KESIMPULAN}

Penelitian ini menemukan; Pertama, Creativity berpengaruh positif pada attitude toward entrepreneurship. Kedua, creativity berpengaruh positif pada subjective norm. Ketiga, creativity berpengaruh positif pada perceived behavioral control. Sesuai dengan teori TPB, attitude dan perceived behavioral control berpengaruh positif pada entrepreneurial intention. Akan tetapi, variabel subjective norm tidak mempunyai pengaruh yang signifikan pada entrepreneurial intention. Hal ini dikarenakan, seluruh responden yang berpartisipasi dalam penelitian ini mempunyai karakter yang sama, yaitu menjunjung nilai 
kolektif sesuai dengan budaya orang timur atau Asia sehingga mereka cenderung akan mengabaikan norma subjektif ketika akan menjadi seorang wirausahawan.

Entrepreneurship education memoderasi secara positif hubungan antara creativity, attitude, subjective norm, perceived behavioral control dan entrepreneurial intention. Artinya, pendidikan kewirausahaan berperan penting dalam menciptakan entrepreneurial intention. Pemberian bekal ilmu pengetahuan serta ketrampilan kewirausahaan akan dapat mendorong orang lebih mempunyai niat untuk berwirausaha. Dengan data responden yang pernah mengikuti entrepreneurship education, efek memoderasi yang dihasilkan pada hubungan antara creativity, attitude, subjective norm, perceived behavioral control dan entrepreneurial intention secara keseluruhan lebih besar untuk responden yang pernah mengikuti pendidikan kewirausahaan dibandingkan dengan responden yang belum pernah mengikuti pendidikan kewirausahaan.

Penelitian selanjutnya diharapkan dapat memperluas sampel responden yang digunakan, dengan mencari data responden yang pernah mengikuti dan belum pernah mengikui pendidikan kewirausahaan secara seimbang sehingga hasil pengujian lebih baik. Selain itu, penelitian selanjutnya diharapkan memperluas penyebaran kuesioner secara geografis (desa dan kota) sehingga lebih relevan dengan fakta lapangsan.

\section{DAFTAR PUSTAKA}

Ajzen, I. (1991). The Theory of Planned Behavior. Organizational Behavior and Human Decision Processes, 50(2), 179-211.

Al Mamun, A., \& Fazal, S. A. (2018). Effect of Entrepreneurial Orientation on Competency and Micro-enterprise Performance. Asia Pacific Journal of Innovation and Entrepreneurship, 12(3), 379-398.

Alain, F., Gailly, B., \& Lassas-Clerc, N. (2006). Effect and Counter-Effect of Entrepreneurship Education and Social Context on Student's Intentions. Estudios de Economía Aplicada, ISSN 1697-5731, Vol. 24, No 2, 2006 (Ejemplar Dedicado a: Empresarialidad), Pags. 509-524, 24.

Baron, R. (2004). The Cognitive Perspective: A Valuable Tool for Answering Entrepreneurship's Basic "Why" Questions. Journal of Business Venturing, 19, 221239.

Bernard, M.-J., \& Barbosa, S. D. (2016). Resilience and Entrepreneurship: A Dynamic and Biographical Approach to the Entrepreneurial Act.M@n@gement, 19(2), 89-123.

Biraglia, A., \& Kadile, V. (2016). The Role of Entrepreneurial Passion and Creativity in Developing Entrepreneurial Intentions: Insights from American Homebrewers: Journal of Small Business Management. Journal of Small Business Management, 55.

Boyd, N. G., \& Vozikis, G. S. (1994). The Influence of Self-Efficacy on the Development of Entrepreneurial Intentions and Actions. Entrepreneurship Theory and Practice, $18(4), 63-77$.

Cardon, M. S., Gregoire, D. A., Stevens, C. E., \& P. C. Patel (2013). "Measuring Entrepreneurial Passion: Conceptual Foundations And Scale Validation." Journal of Business Venturing, 28(3), 373-396.

Chen, C. C., Greene, P. G., \& Crick, A. (1998). Does Entrepreneurial Self-efficacy Distinguish Entrepreneurs from Managers? Journal of Business Venturing, 13(4), 295-316. 
Ernst, K. K. (2011). Heart Over Mind - An Empirical Analysis of Social Entrepreneurial Intention Formation on the Basis of the Theory of Planned Behaviour

Feldman, D., \& Bolino, M. (2000). Career Patterns of the Self-Employed: Career Motivations and Career Outcomes. Journal of Small Business Management, 38.

Ghulam, N. (2008). Graduate Entrepreneurship: Intentions, Education and Training. Education + Training, 50(7), 545-551.

González-López, María Carmen Pérez-López, and Lázaro Rodríguez-Ariza, 2019: Clearing the Hurdles in the Entrepreneurial Race: The Role of Resilience in Entrepreneurship Education. AMLE, 18, 457-483

Gorman, G., Hanlon, D., \& King, W. (2007). Perspectives on Entrepreneurship Education, 56(June).

Gurel, E., Altinay, L., \& Daniele, R. (2010). Tourism Students' Entrepreneurial Intentions. Annals of Tourism Research, 37(3), 646-669.

Habeeb, S., \& Ahmad, N. (2018). Impact of 'Fund of Funds' and Other Initiatives in Building Entrepreneurial Economy of Emerging India: A Comparison with China.

Hair, J. F. (2010). Multivariate Data Analysis. Pearson College Division.

Hair, J. F. J., Black, W. C., Babin, B. J., \& Anderson, R. E. (2009). Multivariate Data Analysis A Global Perspctive (Seventh). Pearson.

Hedner, T., Abouzeedan, A., \& Klofsten, M. (2011). Entrepreneurial Resilience. Annals of Innovation \& Entrepreneurship, 2(1), 7986.

Hunter, S. T., Bedell, K. E., \& Mumford, M. D. (2007). Climate for Creativity: A Quantitative Review. Creativity Research Journal, 19(1), 69-90.

Kolvereid, L. (1996). Prediction of Employment Status Choice Intentions. Entrepreneurship Theory and Practice, 21(1), 47-58.

Krueger, N., \& Brazeal, D. (1994). Entrepreneurial Potential \& Potential Entrepreneurs. Entrepreneurship Theory and Practice, 18.

Krueger, N. F., Reilly, M. D., \& Carsrud, A. L. (2000). Competing Models of Entrepreneurial Intentions. Journal of Business Venturing, 15(5), 411-432.

Kuratko, D. (2005). The Emergence of Entrepreneurship Education: Development, Trends, and Challenges. Entrepreneurship Theory and Practice, 29, 577-598.

Li, Y., Liu, Y., Duan, Y., \& Li, M. (2008). Entrepreneurial Orientation, Strategic Flexibilities and Indigenous Firm Innovation in Transitional China. International Journal of Technology Management - Int J Technol Manage, 41.

Liñán, F., \& Alain, F. (2015). A Systematic Literature Review on Entrepreneurial Intention: 409 Papers List.

Liñán, Francisco \& Chen, Yi-Wen. (2009). Development and Cross-Cultural Application of A Specific Instrument to Measure Entrepreneurial Intentions. Entrepreneurship Theory and Practice. 33. 593 - 617.

Moriano, J., Gorgievski, M., Laguna, M., Stephan, U., \& Zarafshani, K. (2012). A CrossCultural Approach to Understanding Entrepreneurial Intention. Journal of Career Development, 39, 162-185.

Plucker, J., Beghetto, R., \& Dow, G. (2004). Why Isn't Creativity More Important to Educational Psychologists? Potentials, Pitfalls, and Future Directions in Creativity Research. Educational Psychologist, 39, 83-96.

Rauch, A., \& Hulsink, W. (2015). Putting Entrepreneurship Education Where the Intention to Act Lies: An Investigation Into the Impact of Entrepreneurship Education on 
Entrepreneurial Behavior. Academy of Management Learning and Education, The, 14, 187-204.

Robinson, P., \& Sexton, E. (1994). The Effect of Education and Experience on Selfemployment Success. Journal of Business Venturing, 9, 141-156.

Sesen, H. (2013). Personality or Environment? A comprehensive Study on the Entrepreneurial Intentions of University Students. Education + Training, 55(7), 624640.

Sharma, K., Saini, A. L., Nawab, Singh., Ogra, J. L., 1998. Feeding Behaviour and Forage Nutrient Utilization by Goats on a Semi-arid Reconstituted Silvipasture. Asian-Aust. J. Anim. Sci., 11 (4): 344-350

Solesvik, M., Westhead, P., \& Matlay, H. (2014). Cultural Factors and Entrepreneurial Intention: The Role of Entrepreneurship Education. Education and Training, 56, 680696.

Souitaris, V., Zerbinati, S., \& Al-Laham, A. (2007). Do Entrepreneurship Programmes Raise Entrepreneurial Intention of Science and Engineering Students? The Effect of Learning, Inspiration and Resources. Journal of Business Venturing, 22, 566-591.

Sternberg, R. (2004). Culture and Intelligence. The American Psychologist, 59, 325-338.

Teng, B.-S. (2007). Corporate Entrepreneurship Activities Through Strategic Alliances: A Resource-Based Approach Toward Competitive Advantage*. Journal of Management Studies, 44(1), 119-142.

Tiwari, P., Bhat, A., \& Tikoria, J. (2017). An Empirical Analysis of the Factors Affecting Social Entrepreneurial Intentions. Journal of Global Entrepreneurship Research, 7.

Veciana, J., Aponte, M., \& Urbano, D. (2005). University Students' Attitudes Towards Entrepreneurship: A Two Countries Comparison. The International Entrepreneurship and Management Journal, 1, 165-182.

Vesalainen, J., \& Pihkala, T. (1999). Motivation Structure and Entrepreneurial Intentions.

Yang, Y., \& Danes, S. (2015). Resiliency and Resilience Process of Entrepreneurs in New Venture Creation. Entrepreneurship Research Journal, 5, 1-30.

Yar Hamidi, D., Wennberg, K., \& Berglund, H. (2008). Creativity in Entrepreneurship Education. Journal of Small Business and Enterprise Development, 15.

Yordanova, D., \& Tarrazon, M.A. (2010). Gender Differences in Entrepreneurial Intentions: Evidence from Bulgaria. Journal of Developmental Entrepreneurship (JDE), 15, 245-261.

Zahra, S., Korri, J., \& Yu, J. (2005). Cognition and International Entrepreneurship: Implications for Research on International Opportunity Recognition and Exploitation. International Business Review, 14, 129-146.

Zampetakis, L., Gotsi, M., Andriopoulos, C., Moustakis, V., \& Vassilis. (2011). Creativity and Entrepreneurial Intention in Young People Empirical Insights from Business School Students. International Journal of Entrepreneurship and Innovation, 12, 189199. 